\title{
PECULIARITIES OF ESTABLISHMENT AND DEVELOPMENT OF LEGAL RELATIONS IN THE SPHERE OF BORDER SECURITY OF UKRAINE
}

\section{Oleh Hanba}

\section{INTRODUCTION}

Scientific understanding of the nature and essence of legal relations by modern science will contribute to a deeper understanding of the characteristic features of specific legal relations that are inherent to the narrow spheres of law enforcement activities of the state. Namely, the sphere of border security of Ukraine is among them.

The study of the process of origin, formation and development of legal relations in the sphere of border security of Ukraine is instructive and currently important, because it enables us to correctly ascertain their content, structure, specific features within our field of study under present circumstances on the basis of the previous achievements as well as objectively determine their future prospects.

As the expert on the philosophical problems of legal science D. A. Kerimov rightly points out, knowledge of the essential completeness of the legal phenomena of the present (in our case these are legal relations), as well as all their qualitative sides outside the historical processes of evolution, is impossible, since something always remains in society from the past, the principles of the present and the origin of the future $^{1}$. Logical in this approach is the true essence, and historical is its form, which is defined by the specific content. If the historical component makes it possible to investigate legal relations in their complete entirety, with all the coincidences, deviations, details that not rarely distort the objective logic of their development, then the logical component allows us to abstract from minor facts, irrelevant in total, to determine objective characteristics and features of the researched legal relations of a certain historical period, to trace the nature of internal relationships between structural elements (subject, object, content, etc.),

${ }^{1}$ Kerimov D. A. (2001) Metodologiya prava (predmet, funktsii, problemy filosofii prava) [Methodology of law (subject, function, problems of philosophy of law)]. Moscow: Avanta+. P. 110, 115. 
which will contribute to the objectivity and comprehensiveness of the research $^{2}$.

Our research, as it has already been noted, is a special scientific exploration, which is devoted to the study of the peculiarities of the formation and development of legal relations and related legal realities in the sphere of border security of Ukraine. Undoubtedly, they have their own specifics, peculiarities of formation, manifestation, functioning, realization, etc.

Therefore, it is necessary to refer to legal relations origins in the world practice of human coexistence in order to conduct an effective general-theoretical research of their concept.

\section{Development and Regulation of Legal Relations in the Sphere of Border Security of Ukraine (from Ancient Times to the Present)}

In our opinion, the emergence of legal relations in the sphere of border security of Ukraine goes back to the pre-state period and originates from the need to protect the boundaries of the territory of compact residence of the family, fraternity, and tribe. The area of residence of the original social community was of paramount importance to it. After all, such territory included hunting grounds, fish and raw materials resources, berry-fields, wild fruit bushes and trees, natural reserves of building materials, farmlands and other sources of livelihood.

The boundaries of this habitation were largely determined by geographical features such as rivers, forest margins, streams, lake banks, canyons, gorges, mountain ranges, etc. The availability of own assimilated territory, ruled by the relevant human community, was the main condition for its survival, because it provided the resources of daily life for present and future generations. Therefore, the issue of protecting one's own territory of habitation, outlined by certain contingent boundaries, has always been given the highest priority, and in the event of a military threat to its territorial integrity, all material and human resources of a particular social community have been directed to its defence and protection.

The category of "border" from the moment of its formation is decisive in the research of border legal relations, as they arise, change and end up due to its legal or illegal crossing, the movement of goods, animals, permitted or unauthorized goods across it.

${ }^{2}$ Skakun O. F. (2016) Teorija prava i derzhavy [Theory of Law and State]. Kyjiv: Alerta. P. 19-20. 
The concept of "border" in the theory of the state is not only a line on a geographical map, the boundary of a certain geographical space or relevant territory, but also the edge of the space of power, as well as the zone of collision, intersection, mutual overlapping of interests of different structures and areas of power ${ }^{3}$. The above-mentioned action of the power gives rise to a number of various legal relations connected with the defence and protection of the state border, as well as with economic, cultural, humanitarian and other activities within the borderzone.

The concept of "border" was purely conditional, vague, devoid of specifics in the first state formations. Borders were not marked afield in any way, were not constantly protected, were not legally registered and agreed with the neighbouring peoples ${ }^{4}$.

Returning to the origins of our research, it should be emphasized that, according to some scholars, namely the tribe itself was the supreme owner of the territory in which it lived; it was determined by the commonality of economy, culture, way of life, language, relative size of the tribe, etc. 5 . Accordingly, the protection of its own territory, which was characterized in relatively permanent and poorly organized way, was also subject to social regulation through mono-norms of archaic law. At the same time, the protection of contingent borders, boundaries of the territory of habitation (since there were still no official, legally defined borders, as it has already been mentioned) wore collective, at first, spontaneous counteraction in the event of a real threat, which was accompanied by forceful expulsion or destruction of enemies in their own territory. Therefore, the archaic relations that have arisen on this occasion were of the greatest life-changing and, accordingly, obligatoryprotective nature, since such participation was a primary duty of every member of the tribeship, regardless of his/her gender and age.

The moral right to defend and protect one's own territory was based, in our opinion, on the principle of its primacy of settlement by the ancestors of a particular human community of the ancestral society.

The development of the defensive and protective border relations on the lands of Ukraine was facilitated by the formation of the first Slavic

\footnotetext{
${ }^{3}$ Kuprijenko D. A., Dem'janjuk Ju. A., Didenko O. V. (2014) Derzhavna terytorija i derzhavnyj kordon [State territory and state border]. Khmelnytskyi: Vydavnyctvo NADPSU. P. 57.

${ }^{4}$ Kabachynsjkyj M. I. (2005) Istorija okhorony kordoniv Ukrajiny [History of border protection of Ukraine]. Khmelnytskyi: Vyd-vo Nac. akad. Derzh. prykordonnoji sluzhby Ukrajiny imeni Boghdana Khmeljnycjkogho. P. 37.

${ }^{5}$ Danilova V. Yu. (2014) Istoriya pervobytnogo obshchestva [The history of primitive society]. Vladimir: Izd-vo V1GU. P. 40.
} 
states and the construction along the then contingent boundaries of serpentine walls (peculiar land fortifications), the system of guard towns, fortress cities at the intersection of the main trade routes and on the Desna, Ostri, Trubezh, Suli, Ross rivers and other water arteries of the Ukrainian lands of that time, the development of which became the most active during the reign of Vladimir Sviatoslavovych and his son Yaroslav the Wise ${ }^{6}$.

Formation and development of border relations of the Kievan Rus was also facilitated by the improvement of the use of forms and methods of border guard organization (construction of signal towers, use of smoke fires, warning bells, etc.), the main task of which was timely notification of the Prince and his druzhina about approaching the enemy, delaying the advancement of enemy units and the timely setting of special surveillance patrols that have performed observation and reconnaissance functions.

Significant slowdown in the development of border relations was caused by the feudal fragmentation of the lands of Kievan Rus, which in turn resulted in the destruction of the centralized structure of border protection. Thus, each principality began to protect only its borders independently with the help of an outdated system of fortresses with small strength garrisons, which tried to protect, first of all, the centre of the principality?

At the same time in the process of the development of states, their borders and the legal regulation of their defence and protection caused by economic growth and intensive development of trade, legal relations in this sphere were gradually formed and diversified.

However, it should be emphasized that if at the beginning of the emergence of states the protection of their borders was haphazard, spontaneous in nature due to lack of state experience, clearly defined borders, weakness of the legal regulation of the aforementioned sphere, then with the development, first of all, of customs procedures, as a source of state treasury replenishment, there was a need to strengthen the protection of the state border in order to prevent smuggling. To this end, not only casual people, but also professional princely men-at-arms were involved in the protection of the border, permanent guard details were

\footnotetext{
${ }^{6}$ Lytvyn M. M. (2004) Derzhavna prykordonna sluzhba Ukrajiny : istorija ta suchasnistj [State Border Guard Service of Ukraine: History and Modernity]. Kyjiv: PRINT-EKSPRES. P. 12.

${ }^{7}$ Lytvyn M. M. (2004) Derzhavna prykordonna sluzhba Ukrajiny : istorija ta suchasnistj [State Border Guard Service of Ukraine: History and Modernity]. Kyjiv: PRINT-EKSPRES. P. 13.
} 
created, and in later times army units that began to conduct border protection on a professional basis ${ }^{8}$.

The first mention of the organization and activities of the border guards on the borderlands of Ukraine and, accordingly, the beginning of the development of legal relations in this sphere refer to the 40-ies of the XII century. At that time, the weakened hordes of Pincenates, Torkils, Berendeis, and others, known as "black capuches", succumbed to the authority of the Kiev princes, thanks to which they were allowed to reside in the territory of the steppe border-zone for the duty of carrying out patrol border guarding.

However, as I. P. Krypiakevych emphasizes, those steppe settlers he called the predecessors of the Cossacks, although being the debris of the steppe hordes, but maintained their military organization, were quite good in fight and could throw out significant military forces, which were important in the protection of the borders of the state and the borderzone ${ }^{9}$.

The Zaporozhye Cossacks made a significant contribution to the development of various legal relations in the sphere of border security; they became a special manifestation of the Ukrainian military formation performing border tasks and functions ${ }^{10}$. Ever since 1503, an irregular Cossack army consisting of the Cherkasy Cossacks and Cossacks of Prince Dmitry was used to protect the Lithuanian borders from Tatar attacks under the command of "so-called starostas i.e. heads of regions, cities and castles of the state" 11 .

The "Boyars Decision on Cossack Village and Sentry Service" adopted in 1571 in the Moscow kingdom which determined the procedure for the organization of the then border guard service played an

${ }^{8}$ Kabachynsjkyj M. I. (2005) Istorija okhorony kordoniv Ukrajiny [History of border protection of Ukraine]. Khmelnytskyi: Vyd-vo Nac. akad. Derzh. prykordonnoji sluzhby Ukrajiny imeni Boghdana Khmeljnycjkogho. P.18-27.

${ }^{9}$ Kryp'jakevych I., Ghnatevych B., Stefaniv Z. (1992) Istorija ukrajinsjkogho vijsjka (vid knjazhykh chasiv do 20-kh rokiv XX st.) [History of the Ukrainian army (from princely times to the 20 years XX century)]. Ljviv: Svit. P. 22.

10 Mota A. F. (2018) Dijaljnistj Derzhavnoji prykordonnoji sluzhby Ukrajiny z protydiji neleghaljnij mighraciji (administratyvno-pravovyj aspekt) [Activities of the State Border Guard Service of Ukraine on Combating Illegal Migration (Administrative-Legal Aspect)]. Khmelnytskyi: Vydavnyctvo NADPSU. P. 10.

${ }_{11}$ Javornycjkyj D. I. (1991) Istorija zaporizjkykh kozakiv [History of Zaporizhzhya Cossacks]. Ljviv: Svit. P.8. 
important role in the development and improvement of border relations $^{12}$.

Some contribution to the development of migration relations, directly related to the sphere of border security, was made by the Code of Laws of Tsar Olexii Mykhailovych in 1649, which regulated exit procedure to other states with concluded peaceful relations on the basis of a transit charter with a simultaneous ban for exit without such charter. The aforementioned Code of Laws established a differentiated liability of a person for the illegal crossing of the border, depending on the purpose of the illegal crossing ${ }^{13}$.

During the reign of Peter I smuggling was greatly intensified due to the increase in tariff duties on imported goods and the border guards were entrusted with responsibility to strengthen the fight against smuggling. Therefore, a new specialized state body the Commerz College was created in 1718 to fulfil the specified task, as well as to improve the quality of the border service and to expand the regulatory and legal framework of its regulation ${ }^{14}$. The activity of the above-noted body contributed to the development of stable public regulatory as well as security and protection legal relations and the accumulation of positive experience in ensuring the protection of the state border, and, accordingly, the development of legal relations in the border sphere of the Russian Empire, which included the then Ukraine.

Continuing to enhance the regulatory and legal framework of the sphere of border security regulation, improve the quality of the mechanism of legal regulation through the approval and expansion of progressive legal relations, the tsarist government approved the Regulation on the arrangement of military guards along the borders of the western provinces in 1811, which promoted the improvement of quality and effectiveness of official authority application by the personnel, as well as the delineation of jurisdictions of the bodies and

${ }^{12}$ Boyarskiy V. I. (1992) Na storozhe Rusi stoyati [Stand on the watchman of Russia]. Moscow. P. 30.

${ }^{13}$ Karnovich E. P. (1874) Ulozhenie. Sobranie uzakoneniy Russkago gosudarstva; izdanie E. P. Karnovicha. T. I. Tsarstvovanie tsarya Aleksya Mikhaylovicha s 1649 po 1676. [Arrangement. Collection of legalized Russian state; edition of E. P. Karnovich. T. I. The reign of Tsar Alexei Mikhailovich from 1649 to 1676.]. Sankt Peterburg: Tipografiya A. A. Kraevskago. P. 8.

${ }^{14}$ Kabachynsjkyj M. I. (2006) Na varti rubezhiv Batjkivshhyny: Prykordonni vijsjka Ukrajiny v 1991-2003 rokakh [Guarding the Frontiers of the Motherland: Frontier Forces of Ukraine in 1991-2003]. Khmelnytskyi: Vyd-vo Nac. akad. Derzh. prykordonnoji sluzhby Ukrajiny imeni Boghdana Khmeljnycjkogho. P. 272. 
officials of the border guard. Later, the army Disciplinary Charter was introduced in 1877 in order to reinforce the service discipline among border guard personnel.

However, at the end of the XIXth century, despite the attempts to improve the activities of the tsarist border guards by improving the quality of its legal regulation, there was an urgent need to reform it. In this connection, the tsarist power established a Separate Border Guard Corps on October 15, 1893, whose activity was regulated by more sophisticated normative legal documents: the Rules on the Separate Border Guard Corps of 1910; Instruction of the service of the ranks of the Separate Border Guard Corps of 1912; statutes governing the various spheres of its service activity, adopted in 1910-1912, etc. ${ }^{15}$.

Further improvement of the regulatory and legal framework and mechanism of legal regulation of legal relations in the sphere of the border guard service of Ukraine is connected with the activities of Hetman P. P. Skoropadskyi, whose government decided to create a Separate Border Guard Corps in 1918, the effective activity of which was not achieved for a variety of reasons.

Special Border Protection Unit was established under the All-Russian Emergency Commission (AREC) following the restoration of Soviet power in Ukraine, on November 24, 1920. Such protection was provided by the military units of the Red Army on a permanent basis ${ }^{16}$.

Partial improvement of the mechanism of legal regulation of legal relations in the sphere of the state border security in Soviet times is connected with the assertion of Soviet legality and the rule of law of the positivist manner in the spirit of Stalinist ideology.

Qualitatively new approaches to the establishment and improvement of the mechanism of legal regulation of legal relations in the sphere of border security on a European basis began to be implemented after the collapse of the USSR in the time of Ukraine's political independence.

\section{Periods of Evolution of Legal Relations in the Sphere of Border Security in the Conditions of Ukrainian State Formation}

Summarizing the above and analysing relevant historical sources and statutory and regulatory enactments enables us to distinguish the

${ }^{15}$ Kabachynsjkyj M. I. (2008) Istorija kordoniv Ukrajiny [History of Ukraine's borders]. Khmelnytskyi : Vyd-vo Nac. akad. Derzh. prykordon. sluzhby Ukrajiny imeni Boghdana Khmeljnycjkogho. P. 153, 162.

${ }^{16}$ Kabachynsjkyj M. I. (2008) Istorija kordoniv Ukrajiny [History of Ukraine's borders]. Khmelnytskyi : Vyd-vo Nac. akad. Derzh. prykordon. sluzhby Ukrajiny imeni Boghdana Khmeljnycjkogho. P. 186-188, 203. 
following periods of evolution of legal relations in the sphere of border security in the territory of Ukraine:

1) the pre-state period, characterized by the existence of primitive archaic relations, which were governed by the rules of archaic (customary) law and emerged and were realized with regard to the protection of the territory i.e. the particular living space of the original social community, which was the main place of habitation and source of subsistence for them. Such protection was fateful for the tribe as the supreme owner of the territory, so that all available human and material resources of the primitive community were used to secure it;

2) the second state period of establishment and development of relations of the border security sphere concerns the activity of the border guard of the first early feudal state entities of the Eastern Slavic tribes. The Ante State was one of these major state formations, the centre of which, according to scientists, could be Kyiv. It existed for about two centuries and was destroyed by the invasion of nomadic hordes in the beginning of VII century ${ }^{17}$.

It was difficult for the first East Slavic state formations to withstand the invasions of mobile, well-armed nomads for whom military affairs were the usual way of life, so they provided the defense and protection of their own territory mainly through the construction of fortified towns, one of which was in the status of a head one like a center of political and economic life ${ }^{18}$.

Though, the system of fortified towns ensured the assertion of state independence and preservation of material and human resources, it did little to promote border relations related to the improvement of forms and methods of border guard activity, etc.

Border activity improved significantly during the period of strengthening the statehood of Kyivska Rus and the Kingdom of GaliciaVolhynia, which created favourable conditions for the development of its legal regulation and improvement of legal relations in the border sphere. However, the feudal fragmentation, the invasion of the Golden Horde led to the destruction of the centralized structure of the defence and protection of the borders of Kyivska Rus and the slowdown of the

${ }^{17}$ Dnistrjansjkyj M. S. (1992) Kordony Ukrajiny. Terytorialjno-administratyvnyj ustrij [Borders of Ukraine. Territorial and administrative structure]. Ljviv: Svit. P. 11.

${ }^{18}$ Kryp'jakevych I., Ghnatevych B., Stefaniv Z. (1992) Istorija ukrajinsjkogho vijsjka (vid knjazhykh chasiv do 20-kh rokiv XX st.) [History of the Ukrainian army (from princely times to the 20 years XX century)]. Ljviv: Svit. P. 7. 
development of border activity and, accordingly, the legal relations of the aforementioned sphere.

The further restoration of the border function of the Ukrainian state and the intensification of the development of border relations date back to the fourteenth and eighteenth centuries characterized by the loss of Ukraine's state independence, which resulted in the Ukrainian lands being divided between Lithuania, Poland, the Principality of Moldova and Hungary which were characterized by different levels of development and type of government. This led to the fact that the colonization states were forced to protect the Ukrainian territories and form border guard structures, which to some extent facilitated the further development of border relations in the Ukrainian border-zone ${ }^{19}$;

3 ) the third period of evolution of legal relations in the sphere of border security concerns bourgeois statehood, which is characterized by a radical reform of the border service since 1893 in connection with the creation of the Separate Border Guard Corps with its military type manual and a number of normative legal documents that contained progressive legal rules for the detailed regulation of various legal relations in the sphere of border security on a systematic, scientifically substantiated basis. The above-noted regulatory and legal framework successfully operated until 1917, contributing to the development of forms and methods of border activity, and accordingly to the improvement of border relations both in the whole Russian Empire and within the border sphere of Ukraine ${ }^{20}$;

4) the fourth period of evolution of legal relations in the sphere of border security of Ukraine falls on the Soviet stage of state development, which was preceded by an unsuccessful attempt of the Ukrainian national forces to restore and consolidate an independent Ukrainian state in 1917-1921 within its ethnic borders and to create its own border structures of national character. These attempts were carried out in the times of the Central Council and the Hetmanate and the Directory, but none of them was brought to a logical conclusion for objective and subjective reasons ${ }^{21}$. This significantly impeded the development of

${ }^{19}$ Kabachynsjkyj M. I. (2008) Istorija kordoniv Ukrajiny [History of Ukraine's borders]. Khmelnytskyi : Vyd-vo Nac. akad. Derzh. prykordon. sluzhby Ukrajiny imeni Boghdana Khmeljnycjkogho. P. 85.

${ }^{20}$ Lytvyn M. M. (2004) Derzhavna prykordonna sluzhba Ukrajiny : istorija ta suchasnistj [State Border Guard Service of Ukraine: History and Modernity]. Kyjiv: PRINT-EKSPRES. P. 15.

${ }^{21}$ Kabachynsjkyj M. I. (2005) Istorija okhorony kordoniv Ukrajiny [History of border protection of Ukraine]. Khmelnytskyi: Vyd-vo Nac. akad. Derzh. prykordonnoji sluzhby Ukrajiny imeni Boghdana Khmeljnycjkogho. P. 232. 
border infrastructure, the legal basis of border authorities' activity and the legal regulation of border security relations.

Their further evolution is connected with the restoration of power of the Bolsheviks and the accession of Ukraine to the USSR. The system of state border protection instituted in Soviet Russia was automatically extended to Ukraine and other Soviet republics, created on December 30, 1922 by the USSR, despite the recognition of Ukraine's formal independence by resolution of the VIII All-Russian Conference of the Soviet Communist Party on June 1, 1919. In parallel with the numerous, not always justified and deliberate reforms initiated under the ideological pressure of the Bolshevik Party in the sphere of border activity of the Soviet state, positive practical experience has been accumulated in improving the principles, forms and methods of activity of border authorities and bodies, the generalization of which contributed to the improvement of the quality, first of all, of the agency border related rulemaking, which had a positive impact upon the effectiveness of legal relations development within the specified sphere. However, since the 1930s, scientific studies of legal relations in the sphere of border security, and, above all, customs matters have been almost ceased through the monopolization of foreign trade, and the introduction of rigid centralization of state control over the border sphere under the total ideological pressure of the Bolshevik Party ${ }^{22}$;

5 ) the fifth period of evolution of the sphere of our research concerns an independent Ukraine, the peculiarity of which is that they begin to develop on the basis of legal norms of national legislation.

It should be specifically emphasized that the flow of the stated periods of evolution of legal relations in the sphere of border security was not uniform, linear, but it was characterized by ups and downs, stagnation and destruction, etc.

Thus, in the pre-state period of development of tribal societies, these relations were characterized by spontaneity, haphazardness and a certain chaotic nature of their origin and realization on the basis of mono-norms of archaic (customary) law. However, their maximum significancy to the life of the society at the time led to the protection of the tribe's own territory of habitation and the conditional geographical boundaries of its

22 Vasilenko A. I. (2001) Pogranichnaya deyatel'nost'v Rossii: teoriya, praktika $i$ tendentsii razvitiya (konets $X I X-X X$ vv.) [Border activity in Russia: theory, practice and development trends (end of the 19th-20th centuries)] (Doc Thesis), Moscow: Academy of the Federal Border Guard Service of the Russian Federation. P. 234. 
determination as a primary duty of each adult member of the family (tribe).

During the birth of the early Slavic states in the territory of presentday Ukraine, the gradual development of their economy led to the intensification of trade, which was the main condition for the intensification of the development of customs relations in order to replenish the state treasury. The reluctance of the merchants to pay a high fee for the transportation of goods across the border has created massive smuggling i.e. the illegal transportation of goods across the state border bypassing customs posts. This contributed to the development of border security relations caused by the fight against smuggling.

The development of the regulatory and legal framework of the border activity improved with the improvement of the statehood, strengthening of its economic and political basis: the subjective composition of legal relations expanded, the border guard gradually began to be carried out on a continuous professional basis, which contributed to the accumulation of practical experience in the effective implementation of the content of legal relations of the specified sphere, forms and methods of border activity were refined.

The weakening or loss of statehood caused reverse processes in the border sphere: the destruction of a unified system of state border protection, the inhibition of the development of the specified legal relations, the loss of part of own territory as a result of moving the state border line by the enemy for his own benefit, which ultimately led to the breakdown of the regulatory and legal framework on legal relations regulation within the researched sphere.

Therefore, the proper conditions for the development of legal relations in the sphere of border security and the improvement of the regulatory and legal framework for their regulation are only created in a strong, politically and economically stable state.

\section{Peculiarities of Formation and Implementation of Border Security Relations in the Modern Independent Ukrainian State}

Returning to the analysis of the evolution of legal relations in the sphere of border security in the post-Soviet period in connection with the gaining of political independence by Ukraine due to the collapse of the USSR, it should be noted that the further process of development of legal regulation of relations in the investigated sphere largely coincides with 
the stages of the construction of new border structures in independent Ukraine.

Thus, the first stage (1991 - beginning of 1992) is devoted to the problems of creating a regulatory and legal framework for the activity of the Ukrainian Border Guard Troops and developing best practices on the basis of the European principles related to civilized regulation of border relations in close interaction with the public and with the border structures of neighbouring states based on the grounds of the best European and world standards. This contributed to the gradual liquidation of Soviet templates and ideological dogmas in this sphere and the establishment of qualitatively new legal relations through the adoption of a number of regulatory legal enactments: Decree of the Presidium of the Verkhovna Rada of Ukraine of August 30, 1991 No. 1464-XII "On Subordination of the Border Guard Troops Dispositioned in the Territory of Ukraine to Ukraine"; laws of Ukraine: "On the State Border of Ukraine", "On the Border Guard Troops of Ukraine", etc. $^{23,24,25}$.

The second stage (March 9, 1992 - end of 1993) was characterized by the improvement of activities on ensuring the security of the state border of Ukraine and approval of new legal relations by enhancing the mechanism of their legal regulation along with continuing development and expansion of the regulatory and legal framework to meet new challenges and threats to the security of the state border. In this connection, the Cabinet of Ministers of Ukraine adopted the Comprehensive Program for Building the State Border of Ukraine on September 9, 1993 which was approved by the Decree of the President of Ukraine of December 16, 1993 No. 596/93 $3^{26}$. The Law of Ukraine "On

${ }^{23}$ Pro pidporjadkuvannja Ukrajini prykordonnykh vijsjk, shho dyslokujutjsja na jiji terytoriji : Ukaz Prezydiji Verkhovnoji Rady Ukrajiny vid 30 serpnja 1991 roku № 1464-XII. [On subordination of border troops stationed on its territory to Ukraine : Decree of the Presidium of the Verkhovna Rada of Ukraine of August 30, 1991 No. 1464-XII]. Retrieved from: https://zakon.rada.gov.ua/laws/show/1464-12 (accessed 16 October 2019).

${ }^{24}$ Pro derzhavnyj kordon Ukrajiny : Zakon Ukrajiny vid 4 lystopada 1991 roku № 1777XII. [On the State Border of Ukraine : Law of Ukraine of November 4, 1991 No. 1777-XII]. Retrieved from: https://zakon.rada.gov.ua/laws/show/1777-12 (accessed 16 October 2019).

${ }^{25}$ Pro Prykordonni vijsjka Ukrajiny : Zakon Ukrajiny vid 4 lystopada 1991 roku № 1779XII. [On the Frontier Forces of Ukraine : Law of Ukraine of November 4, 1991 No. 1779-XII]. Retrieved from: https://zakon.rada.gov.ua/laws/show/1779-12 (accessed 16 October 2019).

${ }^{26}$ Pro Kompleksnu proghramu rozbudovy derzhavnogho kordonu Ukrajiny : Ukaz Prezydenta Ukrajiny vid 16 ghrudnja 1993 roku № 596/93. [On the Comprehensive Program for Building the State Border of Ukraine : Decree of the President of Ukraine of December 16, 1993 No. 596/93]. Retrieved from: https://zakon.rada.gov.ua/laws/show/596/93 (accessed 17 October 2019). 
General Duty and Military Service" and the Decree of the President of Ukraine of October 7, 1993 No. 431/93 "On Temporary Field Manuals of the Armed Forces of Ukraine" were adopted ${ }^{27,28}$.

The third stage (January 1994 - end of 1999) of the development of legal regulation of relations in the sphere of the state border security of Ukraine is characterized by intensification of the implementation of the Comprehensive Program for Building the State Border of Ukraine provisions aimed at improving the mechanism of legal regulation of relations within the sphere of our research ${ }^{29}$.

The fourth stage (beginning 2000 - March 2003) was marked by a rethinking of the role and status of border structures in the state mechanism of Ukraine, continuation to update the legislative base in order to increase the efficiency of regulation of legal relations and reorganization of the State Border Guard Service of Ukraine into a special purpose law enforcement agency. In this connection, the Decree of the President of Ukraine approved the Program of actions on November, 2000 which was aimed at maintaining the regime of the state border and regulations on restricted access to border areas, the development of the Ukrainian Border Guard Troops and customs authorities for the period up to $2005^{30}$.

The fifth stage (March 27, 2003 - 2014) was characterized by the reorganization of the Border Guard Troops of Ukraine into the State Border Guard Service of Ukraine as a special-purpose law enforcement

${ }^{27}$ Pro vijsjkovyj obov'jazok $i$ vijsjkovu sluzhbu : Zakon Ukrajiny vid 25 bereznja 1992 roku № 2232-XII. [On military duty and military service : Law of Ukraine of March 25, 1992 No. 2232-XII]. Retrieved from: https://zakon.rada.gov.ua/laws/show/2232-12 (accessed 17 October 2019).

${ }^{28}$ Pro tymchasovi statuty Zbrojnykh syl Ukrajiny : Ukaz Prezydenta Ukrajiny vid 7 zhovtnja 1993 roku № 431/93. [On Temporary Statutes of the Armed Forces of Ukraine : Presidential Decree of October 7, 1993 No 431/93]. Retrieved from: https://zakon2.rada.gov.ua/laws/show/\%20431/93?lang=ru (accessed 17 October 2019).

29 Pro Kompleksnu proghramu rozbudovy derzhavnogho kordonu Ukrajiny : Ukaz Prezydenta Ukrajiny vid 16 ghrudnja 1993 roku № 596/93. [On the Comprehensive Program for Building the State Border of Ukraine : Decree of the President of Ukraine of December 16, 1993 No. 596/93]. Retrieved from: https://zakon.rada.gov.ua/laws/show/596/93 (accessed 17 October 2019).

${ }^{30}$ Pro Proghramu dij, sprjamovanykh na pidtrymannja rezhymu derzhavnogho kordonu $i$ prykordonnogho rezhymu, rozvytok Prykordonnykh vijsjk Ukrajiny ta mytnykh orghaniv Ukrajiny na period do 2005 roku : Ukaz Prezydenta Ukrajiny vid 16 lystopada 2000 roku № 1241/2000. [On the Program of Actions aimed at Supporting the State Border and Border Regime, Development of the Border Guard of Ukraine and the Customs Authorities of Ukraine for the Period up to 2005 : Presidential Decree of November 16, 2000 No. 1241/2000]. Retrieved from: https://zakon.rada.gov.ua/laws/show/1241/2000 (accessed 18 October 2019). 
agency, with detailed regulation of its activity, differentiation of competences of different bodies and departments of the agency, which caused expansion of types of legal relations due to the complexity and explicitation of the border agency tasks.

At this stage, the Law of Ukraine "On the State Border Guard Service of Ukraine", the Concept of the State Border Guard Service of Ukraine Development for the Period up to 2015, and other regulatory legal enactments became important documents for determining the strategy of improving the mechanism of legal regulation of legal relations in the sphere of border security of Ukraine ${ }^{31,32}$.

The sixth stage $(2014$ - present $)$ i.e. the improvement of the mechanism of legal regulation of relations in the sphere of border security is characterized by the fact that it accounts for the period of open aggression of the Russian Federation against Ukraine, encroachment upon the territorial integrity and sovereignty of our state, which was manifested in the annexation of the Crimea and Sevastopol, launching military aggression in eastern Ukraine and trying to destroy the unity of the democratic world, by trying to revise the world order that formed after the end of World War II, to undermine the foundations of international security, etc. ${ }^{33}$.

This political situation has caused the urgent need to create a new system of the state border protection, to increase the efficiency of implementation of state policy in the sphere of the state border security, to implement European standards of integrated border management, to create proper conditions for the realization of human rights and freedoms, to develop cross-border cooperation ${ }^{34}$. In this regard, a number

${ }^{31}$ Pro Derzhavnu prykordonnu sluzhbu Ukrajiny : Zakon Ukrajiny vid 3 kvitnja 2003 roku № 661-IV. [On the State Border Guard Service of Ukraine : Law of Ukraine of April 3, 2003 No. 661-IV]. Retrieved from: https://zakon.rada.gov.ua/laws/show/661-15 (accessed 19 October 2019).

${ }^{32}$ Pro Koncepciju rozvytku Derzhavnoji prykordonnoji sluzhby Ukrajiny na period do 2015 roku : Ukaz Prezydenta Ukrajiny vid 19 chervnja 2006 roku № 546/2006. [On the Concept of Development of the State Border Guard Service of Ukraine for the period up to 2015 : Presidential Decree of June 19, 2006 No. 546/2006]. Retrieved from: https://zakon.rada.gov.ua/laws/show/546/2006 (accessed 20 October 2019).

${ }_{33}$ Pro rishennja Rady nacionaljnoji bezpeky i oborony Ukrajiny vid 6 travnja 2015 roku «Pro Strateghiju nacionaljnoji bezpeky Ukrajiny» : Ukaz Prezydenta Ukrajiny vid 26 travnja 2015 roku № 287/2015. [On the Decision of the National Security and Defense Council of Ukraine of May 6, 2015 "On the National Security Strategy of Ukraine" : Presidential Decree of May 26, 2015 No. 287/2015]. Retrieved from: https://zakon.rada.gov.ua/laws/show/287/2015 (accessed 21 October 2019).

34 Pro skhvalennja Strateghiji rozvytku Derzhavnoji prykordonnoji sluzhby : rozporjadzhennja Kabinetu Ministriv Ukrajiny vid 23 lystopada 2015 roku № 1189-r. [On 
of regulatory legal enactments have been adopted aimed at improving the mechanism of legal regulation of relations in the border sphere and the creation of new, more progressive theoretical models of legal relations in the sphere of border activity and implementation of border policy in accordance with the best European and world standards. The following regulatory legal enactments should be referred to: Presidential Decree of January 12, 2015 "On the Strategy for Sustainable Development "Ukraine 2020", Ordinance of the Cabinet of Ministers of Ukraine of November 23, 2015 No. 1189-p. "On Approval of the Strategy for the State Border Guard Service Development", as well as a number of other regulatory legal enactments related to border security issues ${ }^{35,36}$. However, a special place among them is taken by the Law of Ukraine "On National Security of Ukraine",

\section{CONCLUSIONS}

Summarizing the above-mentioned, we can summarize the following conclusions:

legal relations in the sphere of border security of Ukraine have come a long way of evolution in their development, from their pre-state development in the conditions of the patrimonial society as archaic relations of customary law and ending with modern legal relations within the researched sphere;

archaic relationships that arose over the protection of the boundaries of the territory of habitation of a particular social community (family, fraternity, tribe) were extremely fateful and, accordingly, obligatoryprotective in nature, since such participation was a primary duty of every member of the tribeship, regardless of his/her gender and age;

\footnotetext{
Approval of the Strategy of Development of the State Border Service : Order of the Cabinet of Ministers of Ukraine dated November 23, 2015 No. 1189-p.]. Retrieved from: https://zakon.rada.gov.ua/laws/show/1189-2015-p (accessed 22 October 2019).

${ }^{35}$ Pro Strateghiju stalogho rozvytku «Ukrajina-2020»: Ukaz Prezydenta Ukrajiny vid 12 sichnja 2015 roku № 5/2015. [On the Ukraine 2020 Sustainable Development Strategy : Presidential Decree of January 12, 2015, No. 5/2015]. Retrieved from: https://zakon.rada.gov.ua/laws/show/5/2015 (accessed 22 October 2019).

${ }^{36}$ Pro skhvalennja Strateghiji rozvytku Derzhavnoji prykordonnoji sluzhby : rozporjadzhennja Kabinetu Ministriv Ukrajiny vid 23 lystopada 2015 roku № 1189-r. [On Approval of the Strategy of Development of the State Border Service : Order of the Cabinet of Ministers of Ukraine dated November 23, 2015 No. 1189-p.]. Retrieved from: https://zakon.rada.gov.ua/laws/show/1189-2015-p (accessed 22 October 2019).

${ }^{37}$ Pro nacionaljnu bezpeku Ukrajiny : Zakon Ukrajiny vid 21 chervnja 2018 roku № 2469 VIII. [On the National Security of Ukraine : Law of Ukraine of June 21, 2018 No. 2469-VIII]. Retrieved from: https://zakon.rada.gov.ua/laws/show/2469-19 (accessed 23 October 2019).
} 
at the beginning of the emergence of states the protection of their borders was haphazard, spontaneous in nature due to lack of state experience, clearly defined borders, weakness of the legal regulation of the aforementioned sphere, then with the development of customs procedures, as a source of state treasury replenishment, there was a need to strengthen the protection of the state border in order to prevent smuggling;

the development of legal relations in the sphere of border security was not uniform, linear, cyclic in nature but it was characterized by rotating certain ups and downs, which in some way correlate with the stages of development of Ukrainian statehood. Accordingly, the formation of the researched legal relations has been reflected within the five evolutionary periods of their establishment;

the process of development of legal regulation of relations in the sphere of border security in the territory of an independent Ukraine essentially coincides with the six stages of the development of the border guard agency of the Ukrainian state;

the current development of legal regulation and the effective implementation of border security relations are significantly influenced by Ukraine's involvement into a hybrid war with Russia and desire of our country for Euro-Atlantic integration, which contradicts the strategic political plans of the aggressor state.

\section{SUMMARY}

The scientific article is devoted to the research of peculiarities of formation and development of legal relations in the sphere of border security of Ukraine.

The author emphasizes that the origins of modern legal relations within the researched sphere reach back to the pre-state period and originate from the need to protect the boundaries of the territory of compact habitation of the primitive community (family, fraternity, tribe). At the same time, the protection of their own territory was spontaneous, poorly organized and subject to social regulation through mono-norms of archaic law.

It is substantiated that simultaneously with the development of states and their borders, as well as the legal regulation of their defence and protection caused by economic growth, trade and customs development, legal relations in the sphere of border security have been gradually formed and diversified.

Attention is drawn to the fact that the establishment of a mechanism for the legal regulation of legal relations in the sphere of the state border 
security in Soviet times is connected with the establishment of the legitimacy and legal order of the positivist type in the spirit of Stalin's ideology. And qualitatively new approaches to increase the effectiveness of the mechanism of legal regulation of relations in the sphere of border security on a European basis began to be implemented after the collapse of the USSR in the time of Ukraine's political independence.

Five periods of legal relations evolution in the sphere of border security under the difficult conditions of the Ukrainian statehood have been distinguished.

It is also noted that the process of development of legal relations within the researched sphere of independent Ukraine as a whole coincides with the six stages of development and improvement of the activity of its border agency which has been analysed by the author.

\section{REFERENCES}

1. Kerimov D. A. (2001) Metodologiya prava (predmet, funktsii, problemy filosofii prava) [Methodology of law (subject, function, problems of philosophy of law)]. Moscow: Avanta+. (in Russian)

2. Skakun O. F. (2016) Teorija prava i derzhavy [Theory of Law and State]. Kyjiv: Alerta. (in Ukrainian)

3. Kuprijenko D. A., Dem'janjuk Ju. A., Didenko O. V. (2014) Derzhavna terytorija $i$ derzhavnyj kordon [State territory and state border]. Khmelnytskyi: Vydavnyctvo NADPSU. (in Ukrainian)

4. Kabachynsjkyj M. I. (2005) Istorija okhorony kordoniv Ukrajiny [History of border protection of Ukraine]. Khmelnytskyi: Vyd-vo Nac. akad. Derzh. prykordonnoji sluzhby Ukrajiny imeni Boghdana Khmeljnycjkogho. (in Ukrainian)

5. Danilova V. Yu. (2014) Istoriya pervobytnogo obshchestva [The history of primitive society]. Vladimir: Izd-vo VlGU. (in Russian)

6. Lytvyn M. M. (2004) Derzhavna prykordonna sluzhba Ukrajiny: istorija ta suchasnistj [State Border Guard Service of Ukraine: History and Modernity]. Kyjiv: PRINT-EKSPRES. (in Ukrainian)

7. Kryp'jakevych I., Ghnatevych B., Stefaniv Z. (1992) Istorija ukrajinsjkogho vijsjka (vid knjazhykh chasiv do 20-kh rokiv XX st.) [History of the Ukrainian army (from princely times to the 20 years XX century)]. Ljviv: Svit. (in Ukrainian)

8. Mota A. F. (2018) Dijaljnistj Derzhavnoji prykordonnoji sluzhby Ukrajiny z protydiji neleghaljnij mighraciji (administratyvno-pravovyj aspekt) [Activities of the State Border Guard Service of Ukraine on Combating Illegal Migration (Administrative-Legal Aspect)]. Khmelnytskyi: Vydavnyctvo NADPSU. (in Ukrainian) 
9. Javornycjkyj D. I. (1991) Istorija zaporizjkykh kozakiv [History of Zaporizhzhya Cossacks]. Ljviv: Svit. (in Ukrainian)

10. Boyarskiy V. I. (1992) Na storozhe Rusi stoyati [Stand on the watchman of Russia]. Moscow. (in Russian)

11. Karnovich E. P. (1874) Ulozhenie. Sobranie uzakoneniy Russkago gosudarstva; izdanie E. P. Karnovicha. T. I. Tsarstvovanie tsarya Aleksya Mikhaylovicha s 1649 po 1676. [Arrangement. Collection of legalized Russian state; edition of E. P. Karnovich. T. I. The reign of Tsar Alexei Mikhailovich from 1649 to 1676.]. Sankt Peterburg: Tipografiya A. A. Kraevskago. (in Russian)

12. Kabachynsjkyj M. I. (2006) Na varti rubezhiv Batjkivshhyny: Prykordonni vijsjka Ukrajiny v 1991-2003 rokakh [Guarding the Frontiers of the Motherland: Frontier Forces of Ukraine in 1991-2003]. Khmelnytskyi: Vyd-vo Nac. akad. Derzh. prykordonnoji sluzhby Ukrajiny imeni Boghdana Khmeljnycjkogho. (in Ukrainian)

13. Kabachynsjkyj M. I. (2008) Istorija kordoniv Ukrajiny [History of Ukraine's borders]. Khmelnytskyi: Vyd-vo Nac. akad. Derzh. prykordon. sluzhby Ukrajiny imeni Boghdana Khmeljnycjkogho. (in Ukrainian)

14.Dnistrjansjkyj M. S. (1992) Kordony Ukrajiny. Terytorialjnoadministratyvnyj ustrij [Borders of Ukraine. Territorial and administrative structure]. Ljviv: Svit. (in Ukrainian)

15. Vasilenko A. I. (2001) Pogranichnaya deyatel'nost'v Rossii: teoriya, praktika $i$ tendentsii razvitiya (konets $X I X-X X$ vv.) [Border activity in Russia: theory, practice and development trends (end of the 19th-20th centuries)] (Doc Thesis), Moscow: Academy of the Federal Border Guard Service of the Russian Federation.

16. Pro pidporjadkuvannja Ukrajini prykordonnykh vijsjk, shho dyslokujutjsja na jiji terytoriji : Ukaz Prezydiji Verkhovnoji Rady Ukrajiny vid 30 serpnja 1991 roku № 1464-XII. [On subordination of border troops stationed on its territory to Ukraine : Decree of the Presidium of the Verkhovna Rada of Ukraine of August 30, 1991 No. 1464-XII]. Retrieved from: https://zakon.rada.gov.ua/laws/show/1464-12 (accessed 16 October 2019).

17.Pro derzhavnyj kordon Ukrajiny : Zakon Ukrajiny vid 4 lystopada 1991 roku № 1777-XII. [On the State Border of Ukraine : Law of Ukraine of November 4, 1991 No. 1777-XII]. Retrieved from: https://zakon.rada.gov.ua/laws/show/1777-12 (accessed 16 October 2019).

18.Pro Prykordonni vijsjka Ukrajiny : Zakon Ukrajiny vid 4 lystopada 1991 roku № 1779-XII. [On the Frontier Forces of Ukraine : 
Law of Ukraine of November 4, 1991 No. 1779-XII]. Retrieved from: https://zakon.rada.gov.ua/laws/show/1779-12 (accessed 16 October 2019).

19.Pro Kompleksnu proghramu rozbudovy derzhavnogho kordonu Ukrajiny : Ukaz Prezydenta Ukrajiny vid 16 ghrudnja 1993 roku № 596/93. [On the Comprehensive Program for Building the State Border of Ukraine : Decree of the President of Ukraine of December 16, 1993 No. 596/93]. Retrieved from: https://zakon.rada.gov.ua/laws/show/ 596/93 (accessed 17 October 2019).

20.Pro vijsjkovyj obov'jazok $i$ vijsjkovu sluzhbu : Zakon Ukrajiny vid 25 bereznja 1992 roku № 2232-XII. [On military duty and military service : Law of Ukraine of March 25, 1992 No. 2232-XII]. Retrieved from: https://zakon.rada.gov.ua/laws/show/2232-12 (accessed 17 October 2019).

21.Pro tymchasovi statuty Zbrojnykh syl Ukrajiny : Ukaz Prezydenta Ukrajiny vid 7 zhovtnja 1993 roku № 431/93. [On Temporary Statutes of the Armed Forces of Ukraine : Presidential Decree of October 7, 1993 No 431/93]. Retrieved from: https://zakon2.rada.gov.ua/laws/ show/\%20431/93?lang=ru (accessed 17 October 2019).

22.Pro Proghramu dij, sprjamovanykh na pidtrymannja rezhymu derzhavnogho kordonu $i$ prykordonnogho rezhymu, rozvytok Prykordonnykh vijsjk Ukrajiny ta mytnykh orghaniv Ukrajiny na period do 2005 roku : Ukaz Prezydenta Ukrajiny vid 16 lystopada 2000 roku № 1241/2000. [On the Program of Actions aimed at Supporting the State Border and Border Regime, Development of the Border Guard of Ukraine and the Customs Authorities of Ukraine for the Period up to 2005 : Presidential Decree of November 16, 2000 No. 1241/2000]. Retrieved from: https://zakon.rada.gov.ua/laws/show/1241/2000 (accessed 18 October 2019).

23.Pro Derzhavnu prykordonnu sluzhbu Ukrajiny : Zakon Ukrajiny vid 3 kvitnja 2003 roku № 661-IV. [On the State Border Guard Service of Ukraine : Law of Ukraine of April 3, 2003 No. 661-IV]. Retrieved from: https://zakon.rada.gov.ua/laws/show/661-15 (accessed 19 October 2019).

24.Pro Koncepciju rozvytku Derzhavnoji prykordonnoji sluzhby Ukrajiny na period do 2015 roku : Ukaz Prezydenta Ukrajiny vid 19 chervnja 2006 roku № 546/2006. [On the Concept of Development of the State Border Guard Service of Ukraine for the period up to 2015 : Presidential Decree of June 19, 2006 No. 546/2006]. Retrieved from: https://zakon.rada.gov.ua/laws/show/546/2006 (accessed 20 October 2019). 
25. Pro rishennja Rady nacionaljnoji bezpeky $i$ oborony Ukrajiny vid 6 travnja 2015 roku "Pro Strateghiju nacionaljnoji bezpeky Ukrajiny» : Ukaz Prezydenta Ukrajiny vid 26 travnja 2015 roku № 287/2015. [On the Decision of the National Security and Defense Council of Ukraine of May 6, 2015 "On the National Security Strategy of Ukraine": Presidential Decree of May 26, 2015 No. 287/2015]. Retrieved from: https://zakon.rada.gov.ua/laws/show/287/2015

21 October 2019).

26.Pro skhvalennja Strateghiji rozvytku Derzhavnoji prykordonnoji sluzhby : rozporjadzhennja Kabinetu Ministriv Ukrajiny vid 23 lystopada 2015 roku № 1189-r. [On Approval of the Strategy of Development of the State Border Service : Order of the Cabinet of Ministers of Ukraine dated November 23, 2015 No. 1189-p.]. Retrieved from: https://zakon.rada.gov.ua/laws/show/1189-2015-p (accessed 22 October 2019).

27.Pro Strateghiju stalogho rozvytku «Ukrajina-2020»: Ukaz Prezydenta Ukrajiny vid 12 sichnja 2015 roku № 5/2015. [On the Ukraine 2020 Sustainable Development Strategy : Presidential Decree of January 12, 2015, No. 5/2015]. Retrieved from: https://zakon.rada.gov.ua/laws/show/5/2015 (accessed 22 October 2019).

28. Pro nacionaljnu bezpeku Ukrajiny : Zakon Ukrajiny vid 21 chervnja 2018 roku № 2469-VIII. [On the National Security of Ukraine : Law of Ukraine of June 21, 2018 No. 2469-VIII]. Retrieved from: https://zakon.rada.gov.ua/laws/show/2469-19 (accessed 23 October 2019).

\section{Information about the author: Oleh Hanba,} Candidate of Law Sciences, Doctoral student,

Bohdan Khmelnytskyi National Academy of the State Border Guard Service of Ukraine, 4/1 Maiborskyi str., apart. 76, Khmelnytskyi, Ukraine, 29000 ORCID ID: orcid.org/0000-0002-8391-8284 